Pengaruh Sosial Budaya Masyarakat Terhadap Kesehatan

\title{
Pengaruh Dukungan Sosial Terhadap Kesehatan
}

\author{
Iwong Ari Rinaldhi, Muhammad Ali Sodik
}

IIK STRADA INDONESIA

iwongari636@gmail.com, alisodik2012@gmail.com

\begin{abstract}
Abstrak
Pembangunan kesehatan merupakan salah satu bagian dari pembangunan nasional dalam rangkapembangunan sumber daya manusia kearah terciptanya penduduk Indonesia yang sehat, tangguh, mandiridan berkualitas. Pembangunan kesehatan yang dilaksanakan selama ini telah menunjukkan peningkatankondisi kesehatan masyarakat di Kota Padang. Ini dapat dilihat dari indikator kesehatan yaitu menurunnya Angka Kematian Bayi (AKB), menurunnya Angka Kematian Ibu (AKI), meningkatnya angka harapan hidup dan menurunnya penderita Kekurangan Energi dan Protein (KEP). Namun bila dibandingkan dengan kondisi kesehatan masyarakat Indonesia, maka kondisi kesehatan masyarakat Kota Padang masih di bawah ratarata tersebut. Selama ini pembangunan kesehatan dilaksanakan dengan menggunakan pendekatan sakit, yang lebih mengutamakan upaya penyembuhan penyakit dan pemulihan kesehatan. Karena pendekatan ini tidak memberikan manfaat bagi sebagian besar masyarakat dan tidak sesuai dengan perkembangan yang ada, maka pendekatan pembangunan kesehatan berubah kearah pendekatan yang berorientasi sehat, yang lebih mengutamakan upaya pemeliharaan kesehatan dan pencegahan penyakit tanpa mengesampingkan upaya penyembuhan dan rehabilitasi. Salah satu faktor yang menentukan kondisi kesehatan masyarakat adalah perilaku kesehatan masyarakat itu sendiri. Dimana proses terbentuknya perilaku ini dipengaruhi oleh beberapa faktor. Salah satunya adalah faktor sosial budaya, bila faktor tersebut telah tertanam dan terinternalisasi dalam kehidupan dan kegiatan masayarakat ada kecenderungan untuk merubah perilaku yang telah terbentuk tersebut sulit untuk dilakukan.
\end{abstract}

\section{Latar belakang}

Seiring dengan perkembangan ilmu pengetahuan dan teknologi yang banyak membawa perubahan terhadap kehidupan manusia baik dalam hal perubahan pola hidup maupun tatanan sosial termasuk dalam bidang kesehatan yang sering dihadapkan dalam suatu hal yang 
berhubungan langsung dengan norma dan budaya yang dianut oleh masyarakat yang bermukim dalam suatu tempat tertentu.

Pengaruh sosial budaya dalam masyarakat memberikan peranan penting dalam mencapai derajat kesehatan yang setinggi-tingginya. Perkembangan sosial budaya dalam masyarakat merupakan suatu tanda bahwa masyarakat dalam suatu daerah tersebut telah mengalami suatu perubahan dalam proses berfikir. Perubahan sosial dan budaya bisa memberikan dampak positif maupun negatif. Hubungan antara budaya dan kesehatan sangatlah erat hubungannya, sebagai salah satu contoh suatu masyarakat desa yang sederhana dapat bertahan dengan cara pengobatan tertentu sesuai dengan tradisi mereka. Kebudayaan atau kultur dapat membentuk kebiasaan dan respons terhadap kesehatan dan penyakit dalam segala masyarakat tanpa memandang tingkatannya. Karena itulah penting bagi tenaga kesehatan untuk tidak hanya mempromosikan kesehatan, tapi juga membuat mereka mengerti tentang proses terjadinya suatu penyakit dan bagaimana meluruskan keyakinan atau budaya yang dianut hubungannya dengan kesehatan.

\section{Kasus masalah}

1. Untuk mengetahui pengertian kesehatan.

2. Untuk mengetahui Bagaimana hubungan kebudayaan dan pengobatan tradisional.

3. Untuk mengetahui Bagaimana konsep sehat dan sakit menurut budaya masyarakat.

4. Untuk mengetahui faktor pendorong dan penghambat.

5 Untuk mengetahui Bagaimana Solusi Peranan pengobatan tradisional dalam pelayanan kesehatan

\section{Tinjauan Pustaka}

\section{A. Sosial Budaya \\ 1. Pengertian}

Kebudayaan dapat diartikan sebagai hal-hal yang bersangkutan dengan akal. Budaya merupakan perkembangan majemuk dari budidaya yang berarti daya dari budi sehingga dibedakan antara budaya yang berarti daya dari budi berupa cipta, karsa, dan rasa dan kebudayaan yang berarti hasil dari cipta, karsa dan rasa Koentjaraningrat 1990 (dalam Munandar 2000). Kebudayaan atau peradaban 
mengandung pengertian yang luas meliputi pemahaman, perasaan suatu bangsa yang kompleks meliputi pengetahuan, kepercayaan, seni, moral, hukum, adat istiadat (kebiasaan) dan pembawaan lainnya yang diperoleh dari anggota masyarakat.

\section{Faktor Sosial Budaya}

a. Lokasi Klinik

Lokasi klinik atau tempat pelayanan dapat mempengaruhi program KB.

Lokasi klinik diarapkan untuk memudahkan pelayanan, sehingga diperlukan pertimbangan lokasi yang statergis, kelancaran alat transportasi dan dekat keramaian.

\section{b. Petugas KB}

Faktor jenis kelamin, umur dan status perkawinan petugas $\mathrm{KB}$ mempengaruhi keberhasilan program KB. Petugas kesehatan adalah role model di masyarakat, sehingga masyarakat akan cenderung meniru perilaku petugas Kesehatan. c. Waktu Pelayanan Masyarakat sudah menyadari pentingnya KB dan mau mengikuti program $\mathrm{KB}$, namun tidak mempunyai waktu untuk mendatangi klinik KB, dapat menyebabkan mereka lebih memilih tidak menggunakan KB (unmet need). Waktu pelayanan KB sebaiknya disesuaikan dengan keinginan masyarakat dan bukan berdasarkan keinginan petugas

\section{d. Efek Samping}

Efek samping yang timbul dari pemakaian alat kontrasepsi, dapat mengurangi keinginan masyarakat untuk menggunakan alat kontrasepsi. Efek yang terjadi dapat berupa perdarahan, pusing, kegemukan dan flek-flek hitam pada wajah. Banyak kasus Pasangan Usia Subur (PUS) lebih memilih untuk tidak menggunakan KB karena efek samping dari pemakaian alat kontrasepsi.

e. Pengetahuan tentang Metode Kontrasepsi Masyarakat mengenal cara-cara menjarangkan kehamilan secara tradisional. Berbagai cara untuk menjarangkan kehamilan diberbagai daerah, seperti: memperpanjang masa menyusui anak, minum jamu tertentu, melakukan coitus interuptus, pemijatan oleh dukun terhadap ibu yang baru melahirkan.

f. Komunikasi Petugas dengan Masyarakat Kurangnya komunikasi dan penyuluhan yang disampaikan petugas kesehatan kepada masyarakat menyebabkan kurangnya pengetahuan masyarakat 
tentang KB sehingga mereka lebih memilih untuk unmet need.

g. Biaya Pelayanan KB

Pada masyarakat yang taraf ekonomi rendah cenderung tidak mau

mengikuti KB karena tidak mempunyai biaya atau mahalnya biaya pelayanan.

h. Usia Perkawinan Rendah

Tingginya angka kelahiran dipengaruhi oleh usia wanita waktu menikah.

Semakin muda seseorang wanita memasuki jenjang perkawinan, maka semakin panjang masa produktif, berarti semakin panjang kesempatan untuk melahirkan.

i. Adat Perkawinan Poligami

Perkawinan poligami tentunya akan menghambat program KB. Alasan

yang sering digunakan adalah karena tidak mempunyai anak dari jenis kelamin tertentu (laki-laki atau perempuan), sehingga dengan alasan ini seseorang cenderung menikah lagi.

j. Nilai Anak

Sebagian masyarakat dan keluarga sangan mengharapkan kehadiran anak yang banyak. Nilai anak bagi mereka adalah anak dapat memberikan kebahagiaan kepada orang tua, anak sebagai jaminan di hari tua dan membentu ekonomi keluarga, anak memberikan keuntungan ekonomi dan rasa aman bagi keluarganya serta adanya pandangkan bahwa banyak anak banjak rejeki (Maswardi, 2013).

3. Skala Pengukuran Sosial Budaya

Skala yang digunakan untuk mengukur sosial budaya pada penelitian ini menggunakan skala Guttman. Skala ini dikembangkan oleh Louis Guttman. Skala ini mempunyai ciri penting, yaitu merupakan skala kumulatif dan mengukur satu dimensi saja dari satu variabel yang multi dimensi, sehingga skala ini termasuk mempunyai sifat unidimensional. Skala Guttman yang disebut juga metode scalogram atau analisa skala (scale analysis) sangat baik untuk meyakinkan peneliti tentang kesatuan dimensi dari sikap atau sifat yang diteliti, yang sering disebut isi universal (universe of conten).

\section{Pembahasan}

Pengertian Kesehatan

Kesehatan adalah keadaan sejahtera dari badan, jiwa, dan sosial yang memungkinkan setiap orang hidup produktif secara sosial dan ekonomis. Pemeliharaan kesehatan adalah upaya 
penaggulangan dan pencegahan gangguan kesehatan yang memerlukan pemeriksaan, pengobatan dan/atau perawatan termasuk kehamilan dan persalinan. Pendidikan kesehatan adalah proses membantu sesorang, dengan bertindak secara sendiri-sendiri ataupun secara kolektif, untuk membuat keputusan berdasarkan pengetahuan mengenai hal-hal yang mempengaruhi kesehatan pribadinya dan orang lain.

Definisi yang bahkan lebih sederhana diajukan oleh Larry Green dan para koleganya yang menulis bahwa pendidikan kesehatan adalah kombinasi pengalaman belajar yang dirancang untuk mempermudah adaptasi sukarela terhadap perilaku yang kondusif bagi kesehatan. Data terakhir menunjukkan bahwa saat ini lebih dari 80 persen rakyat Indonesia tidak mampu mendapat jaminan kesehatan dari lembaga atau perusahaan di bidang pemeliharaan kesehatan, seperti Akses, Taspen, dan Jamsostek. Golongan masyarakat yang dianggap 'teranaktirikan' dalam hal jaminan kesehatan adalah mereka dari golongan masyarakat kecil dan pedagang. Dalam pelayanan kesehatan, masalah ini menjadi lebih pelik, berhubung dalam manajemen pelayanan kesehatan tidak saja terkait beberapa kelompok manusia, tetapi juga sifat yang khusus dari pelayanan kesehatan itu sendiri.

UU No.23,1992 tentang Kesehatan menyatakan bahwa: Kesehatan adalah keadaan sejahtera dari badan, jiwa dan sosial yang memungkinkan hidup produktif secara sosial dan ekonomi. Dalam pengertian ini maka kesehatan harus dilihat sebagai satu kesatuan yang utuh terdiri dari unsur-unsur fisik, mental dan sosial dan di dalamnya kesehatan jiwa merupakanbagian integral kesehatan.

\section{B. Kebudayaan dan Pengobatan Tradisional}

Masing-masing kebudayaan memiliki berbagai pengobatan untuk penyembuhan anggota masyarakatnya yang sakit. Berbeda dengan ilmu kedokteran yang menganggap bahwa penyebab penyakit adalah kuman, kemudian diberi obat antibiotika dan obat tersebut dapat mematikan kuman penyebab penyakit. Pada masyarakat tradisional, tidak semua penyakit itu disebabkan oleh penyebab biologis. Kadangkala mereka menghubung-hubungkan dengan sesuatu yang gaib, sihir, roh jahat atau iblis yang mengganggu manusia dan menyebabkan sakit. 
Banyak suku di Indonesia menganggap bahwa penyakit itu timbul akibat guna-guna. Orang yang terkena guna-guna akan mendatangi dukun untuk meminta pertolongan. Masing-masing suku di Indonesia memiliki dukun atau tetua adat sebagai penyembuh orang yang terkena guna-guna tersebut. Cara yang digunakan juga berbeda-beda masing-masing suku. Begitu pula suku-suku di dunia, mereka menggunakan pengobatan tradisional masing-masing untuk menyembuhkan anggota sukunya yang sakit.

Suku Azande di Afrika Tengah mempunyai kepercayaan bahwa jika anggota sukunya jari kakinya tertusuk sewaktu sedang berjalan melalui jalan biasa dan dia terkena penyakit tuberkulosis maka dia dianggap terkena serangan sihir. Penyakit itu disebabkan oleh serangan tukang sihirdan korban tidak akan sembuh sampai serangan itu berhenti.

Orang Kwakuit di bagian barat Kanada percaya bahwa penyakit dapat disebabkan oleh dimasukkannya benda asing ke dalam tubuh dan yang terkena dapat mencari pertolongan ke dukun. Dukun itu biasa disebut Shaman. Dengan suatu upacara penyembuhan maka Shaman akan mengeluarkan benda asing itu dari tubuh pasien. [1]

\section{Konsep Sehat dan Sakit Menurut Budaya Masyarakat}

Konsep sehat dan sakit sesungguhnya tidak terlalu mutlak dan universal karena ada faktorfaktor lain diluar kenyataan klinis yang mempengaruhinya terutama faktor sosial budaya. Kedua pengertian saling mempengaruhi dan pengertian yang satu hanya dapat dipahami dalam konteks pengertian yang lain.

Banyak ahli filsafat, biologi, antropologi, sosiologi, kedokteran, dan lain-lain bidang ilmu pengetahuan telah mencoba memberikan pengertian tentang konsep sehat dan sakit ditinjau dari masing-masing disiplin ilmu. Masalah sehat dan sakit merupakan pro seorang pengobat tradisional yang juga menerima pandangan kedokteran modern, mempunyai pengetahuan yang menarik mengenai masalah sakit-sehat. Baginya, arti sakit adalah sebagai berikut: sakit badaniah berarti ada tanda-tanda penyakit di badannya seperti panas tinggi, penglihatan 
lemah, tidak kuat bekerja, sulit makan, tidur terganggu, dan badan lemah atau sakit, maunya tiduran atau istirahat saja. [3]

Persepsi masyarakat mengenai terjadinya penyakit berbeda antara daerah yang satu dengan daerah yang lain, karena tergantung dari kebudayaan yang ada dan berkembang dalam masyarakat tersebut. Persepsi kejadian penyakit yang berlainan dengan ilmu kesehatan sampai saat ini masih ada di masyarakat; dapat turun dari satu generasi ke generasi berikutnya dan bahkan dapat berkembang luas.

Berikut ini contoh persepsi masyarakat tentang penyakit malaria, yang saat ini masih ada di beberapa daerah pedesaan di Papua (Irian Jaya). Makanan pokok penduduk Papua adalah sagu yang tumbuh di daerah rawa -rawa. Selain rawa-rawa, tidak jauh dari mereka tinggal terdapat hutan lebat. Penduduk desa tersebut beranggapan bahwa hutan itu milik penguasa gaib yang dapat menghukum setiap orang yang melanggar ketentuannya.

Pelanggaran dapat berupa menebang, membabat hutan untuk tanah pertanian, dan lain-lain akan diganjar hukuman berupa penyakit dengan gejala demam tinggi, menggigil, dan muntah. Penyakit tersebut dapat sembuh dengan cara minta ampun kepada penguasa hutan, kemudian memetik daun dari pohon tertentu, dibuat ramuan untuk di minum dan dioleskan ke seluruh tubuh penderita. Dalam beberapa hari penderita akan sembuh.

Persepsi masyarakat mengenai penyakit diperoleh dan ditentukan dari penuturan sederhana dan mudah secara turun temurun. Misalnya penyakit akibat kutukan Allah, makhluk gaib, roh-roh jahat, udara busuk, tanaman berbisa, binatang, dan sebagainya. Pada sebagian penduduk Pulau Jawa, dulu penderita demam sangat tinggi diobati dengan cara menyiram air di malam hari. Air yang telah diberi ramuan dan jampi-jampi oleh dukun dan pemuka masyarakat yang disegani digunakan sebagai obat malaria.

D. Faktor Pendorong Dan Penghambat

a. Faktor-Faktor yang Mempengaruhi Perilaku Pengobatan dalam Masyarakat 
Perilaku yang dinyatakan di atas adalah berkaitan dengan upaya atau tindakan individu ketika sedang sakit atau kecelakaan. Tindakan atau perilaku ini bisa melalui dengan cara mengobati sendiri sehingga mencari pengobatan ke luar negeri.

Menurut Blum(1974) yang dipetik dari Notoadmodjo(2007), faktor lingkungan merupakan faktor utama yang mempengaruhi kesehatan individu, kelompok, atau masyarakat manakala faktor perilaku pula merupakan faktor yang kedua terbesar. Disebabkan oleh teori ini, maka kebanyakan intervensi yang dilakukan untuk membina dan meningkatkan lagi kesehatan masyarakat melibatkan kedua faktor ini. Menurut Notoadmodjo juga mengatakan mengikut teori Green(1980), perilaku ini dipengaruhi oleh 3 faktor utama, yaitu:

1. Faktor predisposisi yang mencakup pengetahuan dan sikap masyarakat terhadap kesehatan, tradisi dan kepercayaan masyarakat terhadap hal-hal yang berkaitan dengan kesehatan, sistem nilai yang dianuti masyarakat, tingkat pendidikan, tingkat sosial ekonomi dan sebagainya.

2. Faktor pemungkin yang mencakup ketersediaan sarana dan prasarana atau fasilitas kesehatan bagi masyarakat contohnya fasilitas pelayanan kesehatan.

3. Faktor penguat pula mencakup pengaruh sikap dan perilaku tokoh yang dipandang tinggi oleh masyarakat contohnya tokoh masyarakat dan tokoh agama, sikap dan perilaku para petugas yang sering berinteraksi dengan masyarakat termasuk petugas kesehatan. Selain itu, faktor undang-undang dan peraturan-peraturan yang terkait dengan kesehatan juga termasuk dalam faktor ini. [4]

\section{Kesimpulan}

Untuk menyimpulkan pandangan-pandangan mengenai pengobatan tradisional, saya yakin bahwa jika di nilai dari banyak fungsi yang di harapkan dapat memenuhi oleh pengobatan dan keterbatasan-keterbatasan yang ada pada penelitian medis yang sistematik dalam masyarakatmasyarakat tersebut, maka system-sistem medis tradisional, yang di lihat sebagai sarana adaptif, telah berhasil dengan baik. Mereka telah muncul sejak ribuan tahun yang lalu, telah memberikan harapan dan penyembuhan kepada yang sakit, mereka menangani juga penyakitpenyakit sosial, dan mereka telah memberikan sumbangan terhadap penambahan populasi dunia secara lambat. 
Saya juga percaya bahwa beda dengan pengobatan ilmiah ,baik dari aspek-aspek preventif dan, klinisnya, serta semua kekurangan dalm perawatan kesehatannya maka pengobatan tradisional adalah cara kurang memuaskan dalam memenuhi kebutuhan kesehatan dari penduduk masa kini. Hal ini bukanlah merupakan penilaian kami saja melainkan keputusan para penilai utama, konsumen-konsumen tradisional yang semakin meningkat dalam memilih antara pengobatanya sendiri dengan pengobatanya ilmiah lain.

\section{Daftar Pustaka}

Muhamad Ali Sodik. Pengaruh Dukungan Terhadap Sosial Kesehatan

https://scholar.google.co.id/scholar?hl=id\&as_sdt=0\%2C5\&q=pengaruh+sosial+masyar akat+terhadap+kesehatan\&btnG=\#d=gs_qabs\&u=\%23p\%3DDB3drhKyUDAJ

Makalah Tentang Pengaruh Sosial Budaya Masyarakat Terhadap Kesehatan

https://makalah-xyz.blogspot.com/2019/10/pengaruh-sosial-budaya-

masyarakat.html?m=1

Abstrak Tentang Pengaruh Sosial Budaya Masyarakat Terhadap Kesehatan

http://lib.ui.ac.id/file?file=pdf/abstrak-71470.pdf 
